特集 8

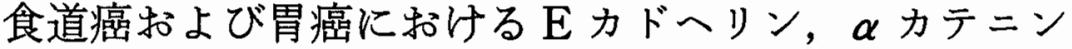 の発現性とリンパ節転移との関連
}

$\begin{array}{llllll}\text { 丮上 } & \text { 大阪大学第 } 2 \text { 外科 } & & \\ \text { 智 } & \text { 塩崎 } & \text { 均 } & \text { 田村 } & \text { 茂行 } \\ \text { 門脇 } & \text { 隆敏 } & \text { 松井 } & \text { 成生 } & \text { 过仲 } & \text { 利政 } \\ \text { 村田 } & \text { 厚夫 } & \text { 西嶌 } & \text { 準一 } & \text { 森 } & \text { 武貞 }\end{array}$

上皮細胞間接着因子である $\mathrm{E}$ 型カドヘリン(以下， E-cad）とカドヘリンの膜裹打ちタンパクでその 機能を制御している $\alpha$ カテニン(以下， $\alpha$-cat）の発現性を食道癌46例と胃癌54例につき免疫組織学的 手法を用い調べた。 また，分化度，浸潤様式，リンパ節転移との相関も検討した。食道癌で E-cad, $\alpha$-cat とも $80.5 \%$, 胃癌で E-cad が57.5\%， $\alpha$-cat が70.4\% と高頻度に発現の減弱·消失が見られ，分化度と 浸潤様式に有意の相関を認めた。リンパ節転移との相関は食道癌の転移陽性例で E-cad, $\alpha \cdot c$-cat とも有 意に低下していたが, 胃癌では $\alpha$-cat とのみ有意差を認めた. E-cad と $\alpha$-cat $の$ coexpression をみる と $\alpha$-cat が E-cadより減弱・消失が高度である症例は食道癌で $45.7 \%$, 胃癌で $27.8 \%$ あ, この上5 な症例で高いリンパ節転移率を示した。すすなわち $\alpha$-cat は E-cad よりリンパ節転移とょり高い相関を 示し，今後術前の転移の検索に有用な因子となりらることが示唆された。

Key words : E-cadherin, $\alpha$-cat, lymphnode metastasis of esophageal and gastric cancer

はじめに

我々は細胞間接着因子である $\mathrm{E}$ 型カドヘリン（以 下, E·cad)が癌組織に扎いて高頻度に減弱し, 癌の転 移・浸潤を引き起こす重要な因子の 1 つであることを 報告してきた ${ }^{1) 21}$. しかし，一部の転移症例では E-cad が発現して扣り必ずしも相関はしなかった，近年報告 された $\alpha$ カテニン（以下， $\alpha$-cat）は細胞内において E-cad の機能を制御していると考学られ³, 今回我々は 癌に拈けるE-cadの発現低下のみでなく, その機能を 検討する目的で, E-cad と $\alpha$-cat の発現を食道癌およ び胃癌につき免疫組織学的手法を用い検討した。 また， 分化度, 浸潤様式, リンパ節転移と $\alpha$-cat の発現性と の相関を調べ, 今後 E-cad とともに $\alpha$-cat も浸潤, 転 移の予知に有用な因子となり得るかを検討した。

\section{対象と方法}

対象は1990年 3 月から1993年 3 月までに当科で手術

*第42回日消外会総会シンポ 2 ・消化器癌の転移の予 知とその対策

$<1993$ 年12月 8 日受理 $>$ 別刷請求先 : 井上 雅智

干565 吹田市山田丘 2-2 大阪大学医学部第 2 外 科
を行った術前未治療の食道癌46例と,胃癌54例である。

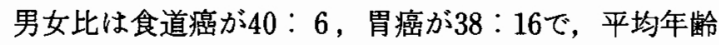
はそれぞれ61.3歳 (40～82歳)，59.8歳（28～82歳）で あった。

新鮮切除標本より，正常粘膜を含む腫瑒組織の凍結 標本の $5 \mu \mathrm{m}$ の連続切片を作成し，それぞれ抗 E-cad モ ノクロナール抗体 (HECD-1), 抗 $\alpha$-catモノクロナー 儿抗体 $(\alpha 18)$ を用い $\mathrm{ABC}$ 法にて免疫組織染色を行っ た. E-cad と $\alpha$-cat の発現性の評価はおの拉のの正常 上皮細胞の発現を陽性の基準とし，これと同等の発現 をしている細胞が $90 \%$ 以上占めている場合を正染 $(+), 90 \sim 10 \%$ を減弱 $( \pm) ， 10 \%$ 末満を消失 $(-)$ と 分類した。

各疾患の臨床病理学的所見と E-cad 括よび $\alpha$-cat の発現性を比較検討した。さらに E-cad と $\alpha$-cat の発 現性の相違を検討した。なお統計処理はMannWhitney 検定により行い, 危険率 $5 \%$ \%下を有意差あ りと判定した.

\section{結 果}

1) E-cad $之 \alpha$-cat の発現性

正常上皮に打けるE-cad と $\alpha$-cat の発現は食道粘 
Fig. 1. Immunohistochemical stainings of E-cadherin (A, C) and $\alpha$-catenin (B, D) in normal epithelium. A, B, esophageal mucosa and C, D, gastric mucosa. E-cadherin and $\alpha$-catenin can be seen on all epithelial cell-cell boundaries. ( $X$ 200)
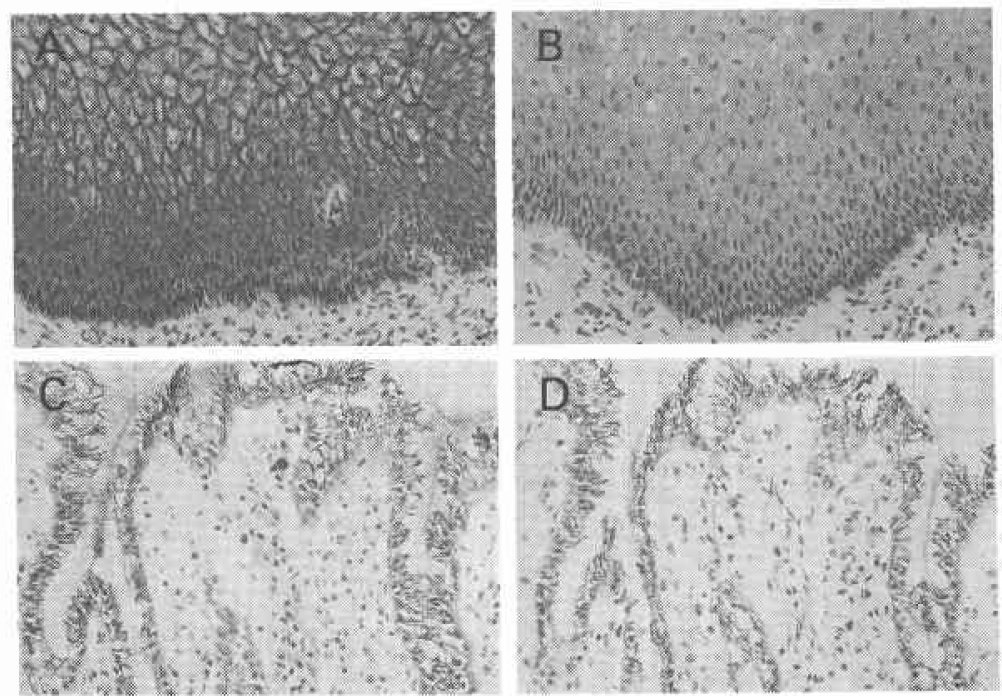

Table 1 Expression of E-cad and $\alpha$-cat in esophageal and gastric cancer

\begin{tabular}{|c|c|c|c|c|c|c|c|}
\hline & \multirow{2}{*}{$\mathrm{n}$} & \multicolumn{3}{|c|}{ E-cad } & \multicolumn{3}{|c|}{$\alpha$-cat } \\
\hline & & $(+)$ & (土) & $(-)$ & $(+)$ & $( \pm)$ & $(-)$ \\
\hline $\begin{array}{l}\text { Esophageal } \\
\text { cancer }\end{array}$ & 46 & $\begin{array}{c}9 \\
(19.5 \%)\end{array}$ & $\begin{array}{c}36 \\
(78.3 \%)\end{array}$ & ( $2.2 \%)$ & $\begin{array}{c}9 \\
(19.6 \%)\end{array}$ & $\begin{array}{c}15 \\
(32.6 \%)\end{array}$ & $\begin{array}{c}22 \\
(47.8 \%)\end{array}$ \\
\hline $\begin{array}{l}\text { Gastric } \\
\text { cancer }\end{array}$ & 54 & $\begin{array}{c}23 \\
(42.5 \%)\end{array}$ & $\begin{array}{c}18 \\
(33.3 \%)\end{array}$ & $\begin{array}{c}13 \\
(24.2 \%)\end{array}$ & $\begin{array}{c}16 \\
(29.6 \%)\end{array}$ & $\begin{array}{c}14 \\
(25.9 \%)\end{array}$ & $(44.5 \%)$ \\
\hline
\end{tabular}

膜，胃粘膜ともに上皮細胞の膜に一致して染色され， 上皮全体に均一に認められた（Fig. 1)，一方，癌組織 においては, E-cad は食道癌で約 $80 \%$, 胃癌で約 $57 \%$ に 減弱あるいは消失しており，また $\alpha$-cat は食道癌で約 $80 \%$, 胃癌で約70\%の減弱が見られた. E-cad と $\alpha$-cat の発現頻度を比較すると, 食道癌, 胃癌ともに $\alpha$-cat は E-cadより減弱あるいは消失する率が高くなっていた (Table 1). 減弱例の染色態度は, 1 切片上に正常発現 している部分と減弱または消失している部分がモザイ ク状に混在しているものが多く， $\alpha$-cat 発現部位では E-cad も発現していたが, 逆は必ずしも一致しなかっ た (Fig. 2).

2) 臨床病理学的所見と E-cad, $\alpha$-cat の発現性

食道癌の分化度と E-cad の発現性の相関を見ると, 分化度が低下するにしたがいE-cad は減弱する傾向 を認めた。 また，浸潤様式と E-cad との相関も浸潤傾 向が強くなるにしたがいE·cadは減弱していた。 $\alpha$ - cat と分化度，浸潤様式との相関も E-cad と同様の傾 向を認めたが，相関係数は $\alpha$-cat の方が高くょり強い 相関を認めた（Table 2). 胃癌においても食道癌と全 く同様の相関を示すデータが得られている.

3）リンパ節転移と E-cad 扎よび $\boldsymbol{\alpha}$-cat の発現性

食道癌の $\mathrm{N}($ （）症例では E-cadが（士）あるいは (一)の比率が $10 / 17(58.8 \%)$ であるのに対し，N(+) 症例では26/29 (89.7\%) と, リンパ節転移陽性症例に おいて E-cad は有意に減弱・消失していた, $\alpha$-catにつ いても $\mathrm{N}($ (一) 症例の $\alpha$-cat (土) または (一) が10/ $17(58.8 \%)$ に対し，N(+) 症例は $27 / 29(93.1 \%)$

と E-cad と同様の相関を示した。

一方, 胃癌に打いてはN (一) 症例の E-cad（土） または（一)が7/20(35.0\%) に対し，N(+)症例で は24/34 (70.6\%) と, リンパ節転移陽性例で E-cad が 減弱する傾向を認めたが有意差はなかった。しかし， $\alpha$-catについてはN (一) 症例での (士), (一) かi8/ 
Fig. 2 Expression of E-cad (A, C) and $\alpha \cdot \operatorname{cat}(B, D)$ in carcinoma. A, B, esophageal cancer and C, D, gastric cancer. Heterogenous expressions of E-cad and $\alpha$-cat and they were classified as E-cad $(+) / \alpha$-cat $(+),(\times 200)$
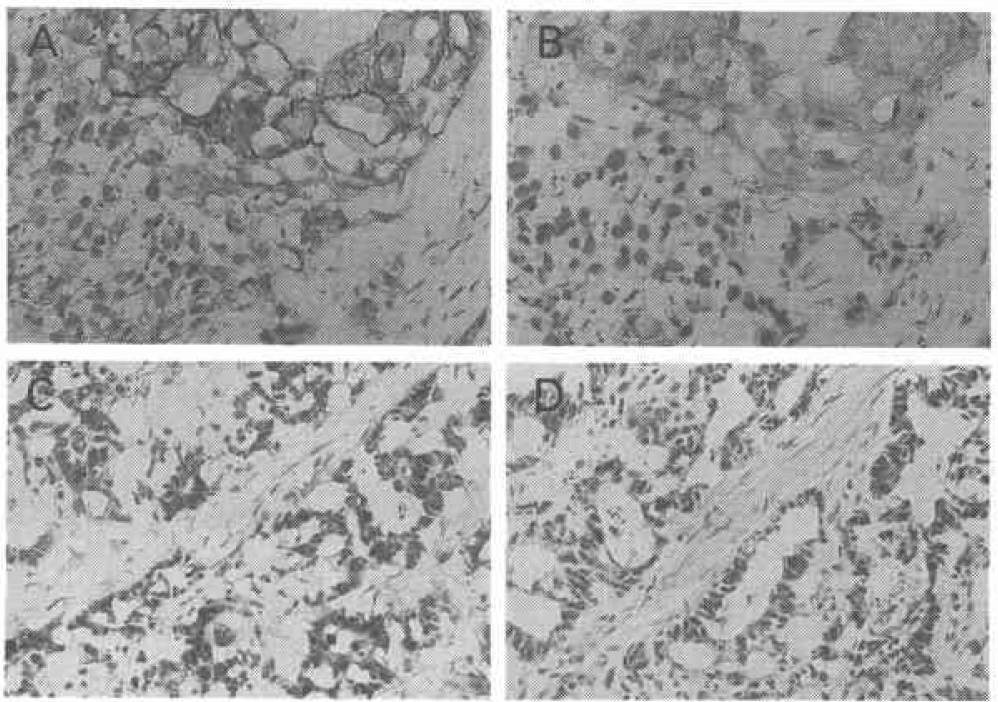

Table 2 Relationship between E-cad and $\alpha$ cat expression and clinicopathological findings in esophageal cancer

\begin{tabular}{|c|c|c|c|c|c|c|c|c|c|}
\hline & \multirow{2}{*}{$\mathrm{n}$} & \multicolumn{3}{|c|}{ E-cad } & \multirow{2}{*}{$\mathrm{p}$ value } & \multicolumn{3}{|c|}{$\alpha$-cat } & \multirow{2}{*}{$\mathrm{p}$ value } \\
\hline & & $(+)$ & $( \pm)$ & $(-)$ & & $(+)$ & $( \pm)$ & $(-)$ & \\
\hline $\begin{array}{l}\text { Differentiation grade } \\
\text { well }\end{array}$ & 18 & 6 & 12 & 0 & & 6 & 7 & 5 & \\
\hline moderlately & 12 & 3 & 9 & 0 & $p<0.01$ & 3 & 3 & 6 & $\mathrm{p}<0.01$ \\
\hline $\begin{array}{l}\text { poorly } \\
\text { Growth pattern }\end{array}$ & 16 & 0 & 15 & 1 & & 0 & 5 & 11 & \\
\hline INF $\quad \alpha$ & 13 & 7 & 6 & 0 & & 7 & 3 & 3 & \\
\hline$\beta$ & 25 & 2 & 22 & 1 & $\mathrm{p}<0.01$ & 2 & 9 & 14 & $\mathrm{p}<0.01$ \\
\hline$\gamma$ & 8 & 0 & 8 & 0 & & 0 & 3 & 5 & \\
\hline
\end{tabular}

Table 3 Relationship between E-cad and $\alpha$-cat expression and lymph node metastasis in esophageal and gastric cancer

\begin{tabular}{cl|r|r|r|r|r|r|r}
\hline & \multirow{2}{*}{} & \multicolumn{3}{|c|}{ E-cad } & \multicolumn{3}{c}{$\alpha$-cat } \\
\cline { 4 - 9 } & & $(+)$ & $( \pm)$ & $(-)$ & $(+)$ & $( \pm)$ & $(-)$ \\
\hline Esophageal & $\mathrm{N}(-)$ & 17 & 7 & 10 & $0^{*}$ & 7 & 7 & $3^{*}$ \\
cancer & $\mathrm{N}(+)$ & 29 & 2 & 26 & 1 & 2 & 8 & 19 \\
Gastric & $\mathrm{N}(-)$ & 20 & 13 & 2 & 5 & 12 & 0 & $8^{*}$ \\
cancer & $\mathrm{N}(+)$ & 34 & 10 & 16 & 8 & 4 & 14 & 16 \\
\hline
\end{tabular}

$\mathrm{N}(-)$ : cancer with no lymph node metastasis

$\mathrm{N}(+)$ : cancer with lymph node metastasis

* $: \mathrm{p}<0.01$
$20(40.0 \%)$ に対し，N(+)症例では30/34 (88.2\%) と有意に転移例で減弱・消失例が多く，リンパ節転移 と $\alpha$-catは E-cadより強い相関を示した (Table 3).

4) E-cad $と \alpha$-cat $の$ co-expression

食道癌に拉いて E-cad と $\alpha$-cat の発現性が一致し ている症例は E-cad $(+) / \alpha$-cat $(+) 9$ 例, $( \pm) /( \pm)$ 15例, (-)/(-)が 1 例で, $\alpha$-cat の発現が E-cad に比 べより強度に減弱あるいは消失している症例は21例 (45.7\%)であった。しかし，逆の発現性を示した症例 は存在しなかった（Table 4), 胃癌の場合も $\alpha$-cat が E-cad より発現の低下している症例は E-cad $(+) / \alpha$ cat (土) 3 例, $(+) /(-) 5$ 例, (土)/(一) 7 例計15 例 $(27.8 \%)$ であり, 逆の発現性を示したものは印環 
Table 4 Relationship between E-cad and $\alpha$-cat expression in esophageal cancer

\begin{tabular}{cc|l|c|c}
\hline & & \multicolumn{3}{|c}{$\alpha$-cat } \\
\cline { 3 - 5 } & & $(+)$ & $( \pm)$ & $(-)$ \\
\hline \multirow{3}{*}{ E-cad } & $(+)$ & $9(2)$ & 0 & 0 \\
& $( \pm)$ & 0 & $15(8)$ & $21(18)$ \\
& $(-)$ & 0 & 0 & $1(1)$ \\
\hline
\end{tabular}

( ) : number of cases with lymph node metastasis

Table 5 Relationship between E-cad and $\alpha$-cat expression in gastric cancer

\begin{tabular}{cc|c|c|c}
\hline \multirow{2}{*}{} & & \multicolumn{3}{|c}{$\alpha$-cat } \\
\cline { 3 - 5 } & $(+)$ & $( \pm)$ & $(-)$ \\
\hline \multirow{4}{*}{ E-cad } & $( \pm)$ & $15(4)$ & $3(3)$ & $5(3)$ \\
& $(-)$ & 0 & $11(11)$ & $7(5)$ \\
& $1(0)$ & 0 & $12(8)$ \\
\hline
\end{tabular}

( ) : number of cases with lymph node metastasis

細胞癌の 1 例のみであった（Table 5).

胃癌の E-cad $(+) / \alpha$-cat $(+)$ 例のリンパ節転移陽 性例は4/15(26.7\%)に比べ, (+)/(士)が3/3(100\%), $(+) /(-)$ が $3 / 5(60.0 \%)$ と $\alpha$-cat が選択的に減弱. 消失している症例に転移が起こる傾向を認めた。食道 癌の E-cad (土)を示した症例も同様の結果であった。

\section{考 察}

癌の転移は腫瘍組織より腫瘍細胞の離脱から始をり 転移藏器への着巣増殖までの間に多くの複雑な機構が 関与している，我々は転移の初段階である腫瘍細胞間

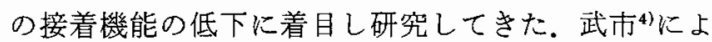
り報告された $\mathrm{E}$ 型カドへリンは膜貫通性の糖タンパ クで, Ca イオン存在下でホモフィリックな結合を行い 細胞間接着因子として正常上皮の組織構築に重要な役 割を担っている。一方, 癌組織ではその発現が減弱し

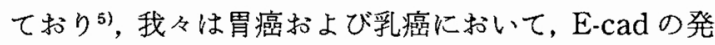
現が分化度や浸潤様式と相関することを報告してき $た^{122) 6}$. 寸なわち, E-cadの減弱により腫瘍細胞の接着 能が低下し，この結果組織構築が崩れ浸潤しやすい状 況になることが明らかになった. 李た，E-cad の低下は 癌の転移にも重要な役割をはたしていると考学られ， 胃癌に沶いてE-cad の減弱あるいは消失している症 例に転移陽性例が多い傾向がみられた。しかし，一部 の症例では E-cad が正常に存在するにもかかわらず 転移を起こしている場合があり，必ずしも転移と $\mathrm{E}$ cadの消失とが一致しなかった。
Fig. 3 Serial sections of a gastric cancer. A, positive expression of $\mathrm{E}$-cad $(+)$ and $\mathrm{B}$, negative expression of $\alpha$-cat $(-) .(\times 200)$
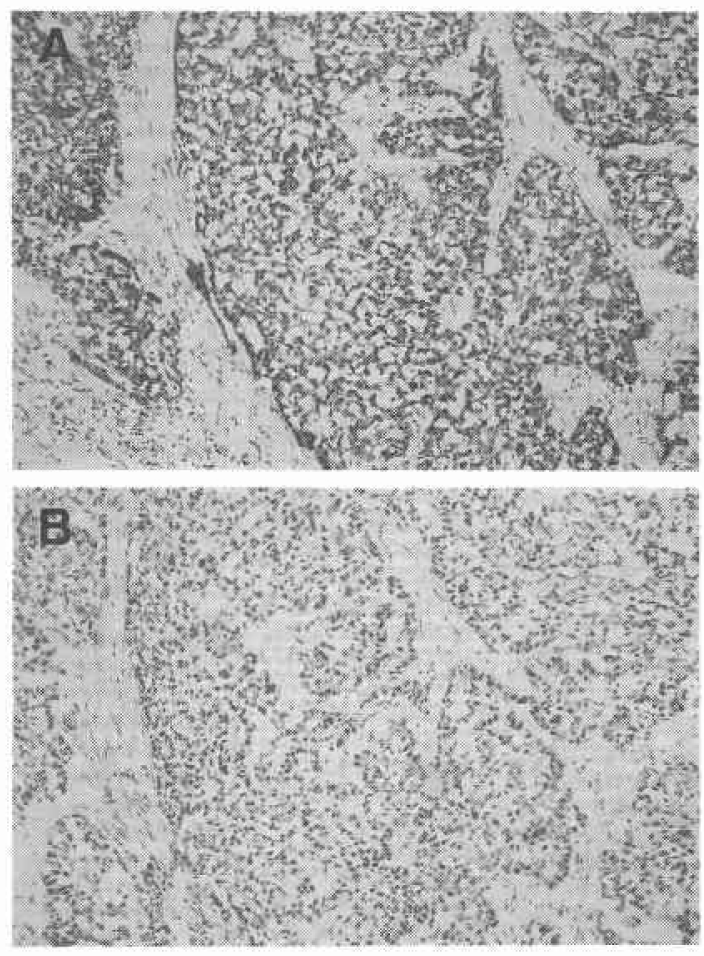

$\alpha$ カテニンは分子量が102kDのタンパク質で，カド ヘリンの細胞膜裏打ちを行い, 細胞内でカドーリンの 機能をコントロールしている因子の1つと考光られて いる。癌細胞において E-cad が存在していても $\alpha$-cat が消失した場合，細胞接着機能の異常をきたし，その 結果漫潤，転移を引き起こすこともあることが考觉ら れる。今回我々は，食道癌と胃癌における E-cad と $\alpha$-cat の発現を免疫組織学的に検討し, また分化度, 浸 潤様式, リンパ節転移と $\alpha$-cat の発現性との相関を検 討した。

食道癌での E-cad と $\alpha$-cat の減弱・消失率はともに $80.5 \%$ であるが，消失例は E-cad が 1 例に対し $\alpha$-cat は22例と $\alpha$-cat がより強く発現の低下を起こしている 傾向がみられた。胃癌についても E-cad の消失例が $13 / 54(24.2 \%)$ に対し， $\alpha$-cat が24/54 (44.5\%) と同 様の結果であった。このことより, 癌に执いて E-cad は発現が減弱しているのみではなく, 正常の発現をし ていてもその機能が低下している場合もあると考克ら れる.

E-cad と $\alpha$-cat はその機能の点から考光, 癌の分化 
度や浸潤様式と相関することが推測されるが，今回の 検討でも分化傾向が低くなるほど，また浸潤傾向が強 くなるほどE-cad と $\alpha$-cat は発現が減弱していた。

次に, リンバ節転移と E-cad, $\alpha$-cat の発現性との関 係は, 食道癌のリンパ節転移陽性例で E-cad と $\alpha$-cat が有意に低下していたが, 胃癌では E-cad との間に有 意な相関がみられなかった。これは E-cad が正常発現 した症例にもリンパ節転移が比較的高頻度に認めたた めで,このような症例では E-cad の機能が低下してい ると推測された. そこで, E-cad と $\alpha$-cat の coexpressionを検討してみると食道癌, 胃癌とも E-cadの減 弱・消失した症例ではほぼ全例で $\alpha$-cat も低下してお り, また, E-cadより $\alpha$-catがより強度に発現の低下を 示した症例が食道癌で $45.7 \%$, 胃癌で $27.8 \%$ 存在した。 このことより， $\alpha$-cat は E-cad が減弱あるいは消失す れば必ず同様に存在しえなくなり，消失することが示 唆された。 また, E-cadが正常発現していても $\alpha$-cat が 減弱あるいは消失し, この結果 E-cad の機能異常を起 こしていると思われる症例の存在が判明した，確かに このよらな症例にリンパ節転移の多い傾向を認めた。

以上より， $\alpha$-cat は食道癌, 胃癌において E-cadより リンパ節転移とより高い相関を示し, 今後術前のリン パ節転移の検索に有用な因子となりえることが示唆さ れた。
稿を終わるにあたりヒト抗 $\alpha$ カニンモノクロナール 抗体 ( $\alpha 18)$ の御供与をいただきました岡崎生理学研究所教 授月田承一郎先生に深謝いたします。

\section{文 献}

1) Shiozaki H, Tahara H, Oka $\mathrm{H}$ et al: Expression of immunoreactive E-cadherin adhesion molecule in human cancers. Am J Pathol 139 : 17-23, 1991

2) Oka $H$, Shiozaki $H$, Kobayashi $K$ et al: Immunohistochemical evaluation of E-cadherin adhesion molecule expression in human gastric cancer. Virchow Arch (A) 421:149-156, 1992

3) Nagafuchi A, Takeichi $M$, Tsukita $S$ : The $102 \mathrm{kD}$ cadherin-associated protein: similarity to vinculin and posttranscriptional regulation of expression. Cell $65: 849-857,1991$

4) Takeichi M: Functional correlation between cell adhesive properties and some cell surface protains. J Cell Biol $75: 464-474,1977$

5) Shimoyama Y, Hirohashi S: Expression Eand-P.cadherin in gastric cancer. Cancer Res $51: 2185-2192,1991$

6) Oka H, Shiozaki $H$, Kobayashi $K$ et al: Expression of E-cadherin cell adhesion molecules in human breast cancer tissues and its relationship to metastasis. Cancer Res 53 : 1696-1701, 1993

\title{
Relationship between E-cadherin and $\alpha$-catenin Expression and Lymphnode Metastasis of Esophageal and Gastric Cancer
}

\author{
Masatoshi Inoue, Hitoshi Shiozaki, Shigeyuki Tamura, Takatoshi Kadowaki, Shigeo Matsui, \\ Toshimasa Tsujinaka, Atsuo Murata, Junichi Nishijima and Takesada Mori \\ Department of Surgery II, Osaka University Medical School
}

In 46 esophageal cancers and 54 gastric cancers, we examined the expression of E-cadherin (E-cad), adhesion moleclues, and $\alpha$-catenin ( $\alpha$-cat), an E-cad-associated cytoplasmic protein that regulates E-cad function, using immunohistochemical methods. We also examined the relationship between E-cad and $\alpha$-cat expression and clinicopathological features. The expression of $\alpha$-cat, as well as that of E-cad, was significantly reduced in esophageal cancers (80.5\%) and gastric cancers $(70.4 \%)$. The reductions in E-cad and $\alpha$-cat were significantly correlated with invasiveness and differentiation grade, but $\mathrm{E}$-cad expression was not correlated with lymph node metastasis in gastric cancers. We also examined co-expression of E-cad and $\alpha$-cat. In 46 esophageal cancerous lesions, 21 cases showed dominant reduction of $\alpha$-cat, and 15 of 54 gastric cancerous lesions showed the same reduction. Furthermore, the frequency of lymph node metastasis was high in these cases. These results suggest that the reduction of $\alpha$-cat expression is more closely correlated with invasiveness and lymph node metastasis than that of E-cad expression, and that $\alpha$-cat may be a useful factor to investigate lymph node metastasis preoperatively in esophageal and gastric cancer.

\section{Reprint requests: Masatoshi Inoue Department of Surgery II, Osaka University Medical School} 2-2 Yamadaoka, Suita, Osaka, 565 JAPAN 